\title{
IN VIVO EXAMINATION OF THE LENS BY THE PHASE-CONTRAST MICROSCOPE*
}

\author{
BY \\ J. FRANÇOIS AND M. RABAEY † \\ From the Ophthalmological Clinic, University of Ghent
}

IT has always been a difficult problem to render visible the microscopical detail of transparent material immersed in a fluid of similar refractive index. This difficulty has now been largely overcome by the phase-contrast microscope introduced by the Dutch physicist Zernike between 1934 and 1942.

When rays of light pass through transparent cells in an aqueous medium they acquire slight phase differences which are so small that the observed differences in intensity are negligible under ordinary conditions. The principle of the phase-contrast microscope + depends upon the introduction of a phase plate into the focal plane of the objective which converts these slight differences of phase into appreciable changes in intensity.

This technique is of value in the examination of the lens, for the tissues may be studied in their natural and living state without alteration by the vigorous action of fixation and staining. This preliminary report is intended to emphasize the value of this new method and to give an account of some of the findings.

The lens capsule itself is seen as an entirely homogeneous and structureless membrane, but the subcapsular epithelium is of particular interest.

The epithelial cells of a human cataractous lens are seen to be well arranged with distinct nuclei (Fig. 1: human cataractous lens epithelium). Two types of cell may be distinguished: one pale and polyhedral, and the other dark and star-shaped, with protcplasmic prolongations which extend between the pale cells. Both types of cell were seen in all specimens of lens epithelium examined.

The lens epithelium under a higher magnification (Fig. 2: normal lens epithelium) shows very clearly defined homogeneous nuclei with well demarcated nucleoli. It is interesting to note that the granularity seen in the nucleus in fixed and stained specimens is probably due to coagulation of the cell. At this magnification the

* Received for publication January 25, 1951.

+ In receipt of a grant from the Belgian National Fund for Scientific Research.

$\ddagger$ The phase-contrast microscope used in our investigations was made by Wild and Co., Heerbrugg Switzerland. It is supplied with four "phase" objectives $(\mathrm{Ph} 70.20 ; \mathrm{Ph} \mathrm{20} 0.45 ; \mathrm{Ph} 400.66 ; \mathrm{Ph} 85,1.25$ immersion), and three oculars $(5 x, 7 x$, and $10 x)$. 


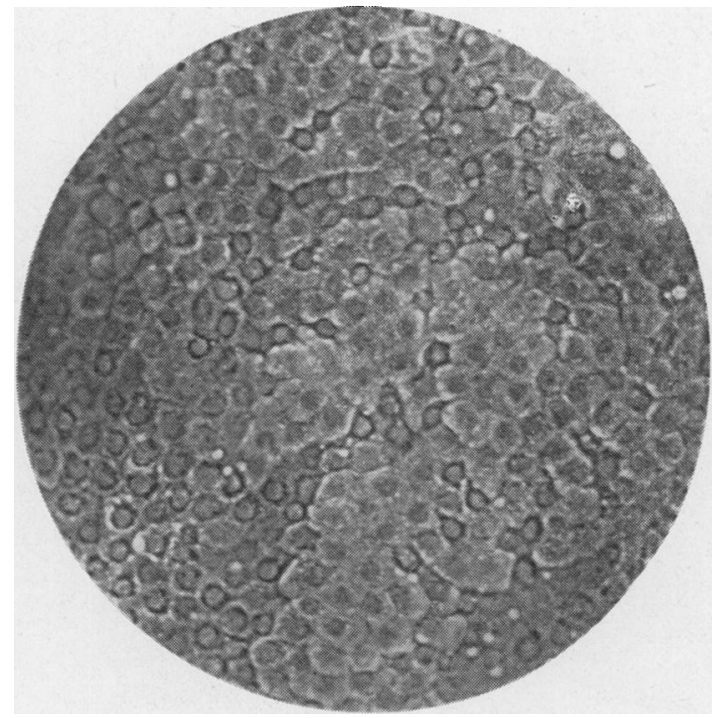

FIG. 1.-Epithelial cells of human cataractous lens well arranged with distinct nuclei. Two types of cell may be seen ; one pale and polyhedral, the other dark and star-shaped. Phase-contrast photomicrograph. Objective 40. Ocular 8.

FIG. 2.-Normal lens epithelium under a higher magnification showing clearly defined homogeneous nuclei with well demarcated nucleoli. The star-shaped cells and small vacuoles are clearly visible. Phase-contrast photomicrograph. Objective 85 . Oil immersion. Ocular 8.

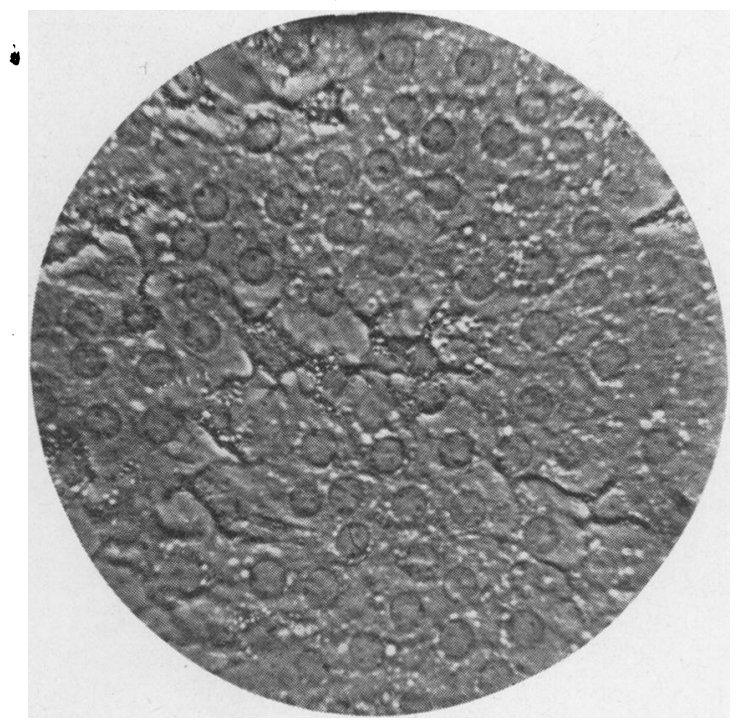

star-shaped cells were clearly visible and small vacuoles were noted around the nuclei in both types of cell.

In the peri-nuclear area of almost all the polyhedral cells a large number of regular granulations was seen (Fig. 3). They varied in quantity but were present in all the preparations: more granulations were present where the star-shaped cells were scanty.

In the lenses from cattle used in the experiment there was seen a 


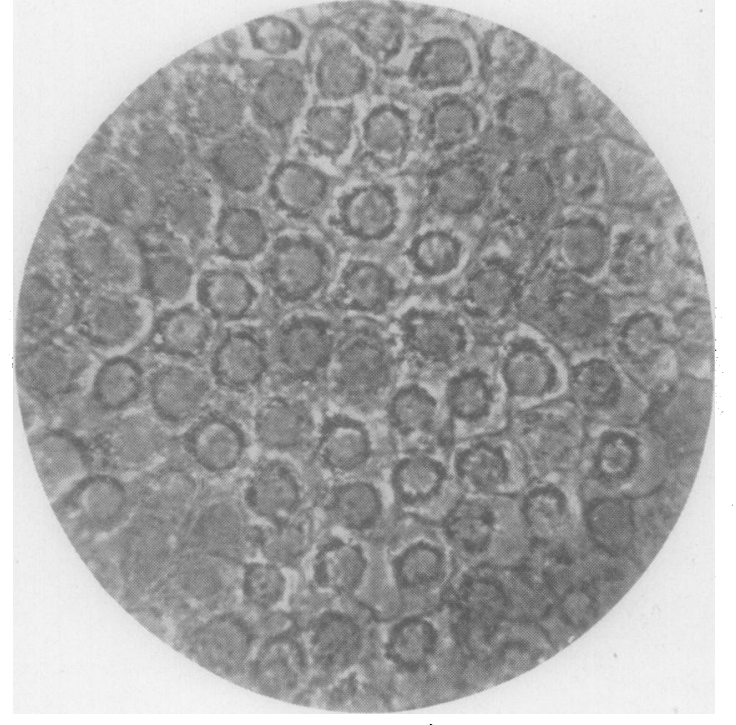

FIG. 3.-Polyhedral cells showing a large number of regular granulations in peri-nuclear area. Phasecontrast photomicrograph. Objective 85. Oil immersion. Ocular $\times 8$.

Fig. 4.-Transformation of epithelial cells into lens fibres. Nuclei arranged in regular rows. Numerous starshaped cells are seen. Phase -contrast photomicrograph. Objective 40. Ocular $\times 8$.

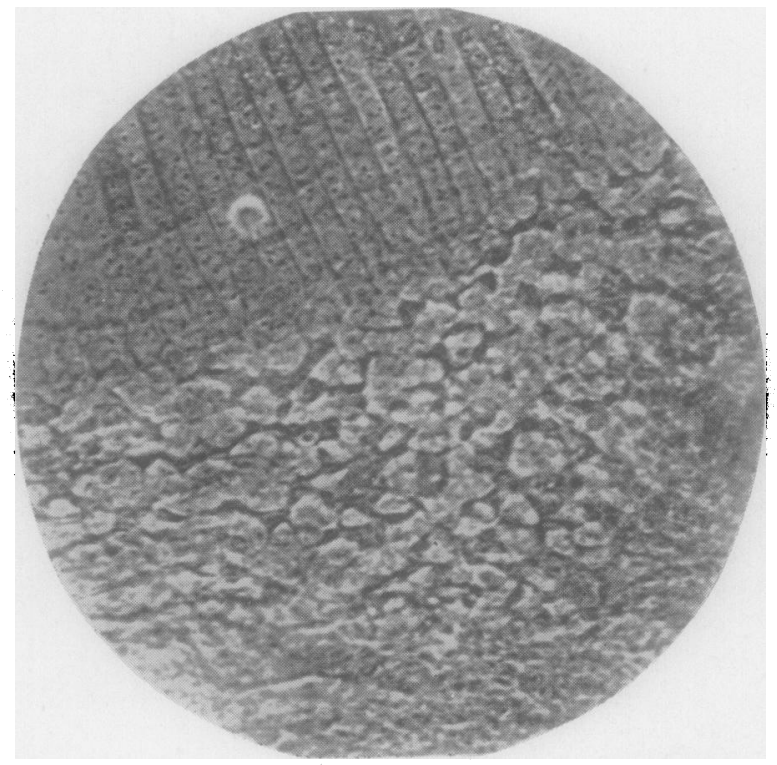

markedly increasing vacuolization in the cells. In some cases the small vacuoles had coalesced within the cytoplasm leaving only the cell membrane remaining. It is, therefore, evident that this process precedes the death of the cell.

The transformation of the epithelial cells into lens fibres was studied in the pig lens (Fig. 4). Here again, numerous dark, star- 
shaped cells were distinctly seen. The nuclei were found to be arranged in regular rows where lens fibres were developing. Note the undulating lines crossing the developing lens fibres perpendicularly.

Hasty conclusions should not be drawn but one may assert that the phase-contrast microscope shows two kinds of cell in the lens epithelium, i.e., the pale, polyhedral cells and dark, star-shaped cells. Attention, however, should be drawn to the presence of the granulations which were regularly observed. Such granulations have been noted previously and named plastosomes or chondriosomes (Busacca, 1925, 1927). There is reason to believe that these granulations have a well-defined structure and that they are connected with enzymatic reactions. They are thus extremely important, not only in the metabolism of the cell itself but also in relation to the surrounding tissue. Nadi-positive granulations (oxydase) were demonstrated in the epithelial cells of the lens by Rauh (1933).

It is also pointed out that the phase-contrast microscope demonstrates particularly well the vacuolization of the cells which progresses to their final disintegration.

\section{REFERENCES}

BusacCA, A. (1925). Boll. Oculist., 4, 572.

(1927). Monit. zool. ital., 38, 271.

Hess, C. (1911). " Pathologie und Therapie des Linsensystems", comprising Teil 2, Kap 9 of A. Graefe and T. Saemisch, " Handbuch der gesamten Augenheilkunde ", 3rd ed. Engelmann, Leipzig.

RauH, W. (1933). Graefes Arch. Ophthal., 130, 213.

ZernIKe, F. (1942). Physica, Eindhoven, 9, 686, 979. 